\title{
Comparison of Ruminal Degradability, Indigestible Neutral Detergent Fiber, and Total-Tract Digestibility of Three Main Crop Straws with Alfalfa Hay and Corn Silage
}

\author{
Erdan Wang (D), Jidong Wang, Jiaying Lv, Xiaoge Sun (D), Fanlin Kong, Shuo Wang, Yajing Wang, Hongjian Yang (D, \\ Zhijun Cao (D), Shengli Li and Wei Wang *
}

\author{
Beijing Engineering Technology Research Center of Raw Milk Quality and Safety Control, State Key Laboratory \\ of Animal Nutrition, College of Animal Science and Technology, China Agricultural University, No. 2 \\ Yuanmingyuan West Road, Haidian, Beijing 100193, China; wangerdan@cau.edu.cn (E.W.); \\ SY20203040696@cau.edu.cn (J.W.); b20183040337@cau.edu.cn (J.L.); B20193040347@cau.edu.cn (X.S.); \\ fanlinkong@cau.edu.cn (F.K.); b20213040351@cau.edu.cn (S.W.); yajingwang@cau.edu.cn (Y.W.); \\ yang_hongiian@sina.com (H.Y.); caozhijun@cau.edu.cn (Z.C.); lisheng0677@163.com (S.L.) \\ * Correspondence: wei.wang@cau.edu.cn; Tel.: +86-010-62731254
}

Citation: Wang, E.; Wang, J.; Lv, J.; Sun, X.; Kong, F.; Wang, S.; Wang, Y.; Yang, H.; Cao, Z.; Li, S.; et al.

Comparison of Ruminal Degradability, Indigestible Neutral Detergent Fiber, and Total-Tract Digestibility of Three Main Crop Straws with Alfalfa Hay and Corn Silage. Animals 2021, 11, 3218. https://doi.org/10.3390/ ani11113218

Academic Editors: Yimin Cai, Zaenal Bachruddin and Jianguo Zhang

Received: 22 September 2021 Accepted: 8 November 2021 Published: 11 November 2021

Publisher's Note: MDPI stays neutral with regard to jurisdictional claims in published maps and institutional affiliations.

Copyright: (c) 2021 by the authors. Licensee MDPI, Basel, Switzerland. This article is an open access article distributed under the terms and conditions of the Creative Commons Attribution (CC BY) license (https:// creativecommons.org/licenses/by/ $4.0 /)$.
Simple Summary: Corn straw (Zea mays, CS), rice straw (Oryza sativa, RS), and wheat straw (Triticum aestivum, WS) are the three main crop straws worldwide. Few studies on indigestible neutral detergent fiber (iNDF) and total-tract digestibility (TTD) of crude protein (CP), neutral detergent fiber (NDF), and acid detergent fiber (ADF) of these crop straws are available, which limits their utilization in dairy diets. Here, we compared the ruminal degradability, $\mathrm{iNDF}_{288}$ content, intestinal digestibility, and TTD for the CP, NDF, and ADF of these three crop straws with alfalfa hay (Medicago sativa, AH) and corn silage (Zea mays, CSil). The results showed that CS, RS, and WS had higher ruminal potential NDF degradation, intestinal digestible $\mathrm{CP}$, and lower $\mathrm{iNDF}_{288}$ content compared to $\mathrm{AH}$. Greater accuracies for regression equations capable of predicting the $\mathrm{iNDF}_{288}$ content and TTD were also generated based on chemical composition and ruminal degradation kinetics. Incorporating this information into rations could improve our ability to optimize the utilization of main crop straws in balanced dairy diets.

\begin{abstract}
Three main crop straws including corn straw (Zea mays, CS), rice straw (Oryza sativa, RS), and wheat straw (Triticum aestivum, WS), and two forages including alfalfa hay (Medicago sativa, AH) and corn silage (Zea mays, CSil) were analyzed in order to compare their ruminal degradability, indigestible neutral detergent fiber (iNDF), intestinal digestibility (ID), and their total-tract digestibility (TTD) of crude protein (CP), neutral detergent fiber (NDF), and acid detergent fiber (ADF) using both an in situ nylon bag technique and a mobile nylon bag technique. The forage samples were incubated in the rumen for $6,12,16,24,36,48,72$, and $288 \mathrm{~h}$, respectively, to determine their ruminal degradability. Prior to intestinal incubation, forage samples were incubated in the rumen for $12 \mathrm{~h}$ and $24 \mathrm{~h}$ to determine the ruminal degradable content of $\mathrm{CP}, \mathrm{NDF}$, and ADF, respectively, and for $288 \mathrm{~h}$ to determine their $\mathrm{iNDF}_{288}$ content. Residues from the ruminal undegradable fractions $(12 \mathrm{~h}$ for $\mathrm{CP}, 24 \mathrm{~h}$ for NDF and ADF) were subsequently inserted into the duodenum through a cannula to determine their intestinal digestible content. Here, the TTD of CP, NDF, and ADF were determined as the ruminal degradable content + intestinal digestible content. The results showed that $\mathrm{AH}$ had the highest $\mathrm{iNDF}_{2.4}$ (calculated as acid detergent lignin content $\times 2.4$ ) and $\mathrm{iNDF}_{288}$ values (379.42 and $473.40 \mathrm{~g} / \mathrm{kg}$ of NDF), while CS and CSil had the lowest $\mathrm{NDF}_{2.4}$ values $(177.44$ and $179.43 \mathrm{~g} / \mathrm{kg}$ of NDF). The ruminal degradability of CP, NDF, and ADF for CS, RS, and WS were lower than those of $\mathrm{AH}$ and $\mathrm{Csil}$ during the first $48 \mathrm{~h}$ of incubation. The potential degradation fraction of $\mathrm{CP}, \mathrm{NDF}$, and ADF for CSil was the highest; CS, RS, and WS were intermediate; and AH was the lowest $(p<0.05)$. CS, RS, and WS had a lower intestinal digestibility with respect to their rumen undegradable content of NDF $(p<0.05)$, and lower TTD of CP, NDF, and ADF $(p<0.05)$ compared to AH and CSil. General regression equations with satisfactory accuracy $\left(R^{2} \geq 0.828\right)$ were derived to predict $\mathrm{iNDF}_{288}$ and TTD based on their chemical compositions and the ruminal degradation kinetics of different forages.
\end{abstract}


Incorporating this information into rations could improve our ability to optimize main crop straws utilization and milk production.

Keywords: main crop straws; ruminal degradability; indigestible neutral detergent fiber; totaltract digestibility

\section{Introduction}

Corn straw (Zea mays, CS), rice straw (Oryza sativa, RS), and wheat straw (Triticum aestivum, WS) are the main crop straws due to the fact that corn, wheat, and rice are the main grain crops consumed worldwide (with a production of 1125, 775.8, and 505 million metric tons, respectively, in 2020-2021) [1]. Particularly, China generates over 600 million tons of crop straws annually, of which CS, RS, and WS make up the top three components of the national yield [2-5]. With a national utilization rate of $80 \%$ in 2015, there is still a large amount of crop straw that is burned in open fields, resulting in not only environmental pollution but also underutilization of biomass resources [3].

Rumen depends on rumen microorganisms, which represent one of the most elegant and efficient cellulose-digesting systems in nature [6-8]. Ruminants can convert low-value plant biomass into high-value animal protein including milk, meat, and fiber products, while also releasing methane $\left(\mathrm{CH}_{4}\right)$, the single largest anthropogenic greenhouse gas $[9,10]$. However, the nutritional value of crop straws was reported to be low due to their low contents of crude protein (CP), metabolizable energy (ME), minerals, and vitamins, and high contents of polysaccharides, lignin, and silica content, which may restrict their use as feed for ruminants [11-13]. Moreover, when CS is fed as the main forage in diets, the production performance of livestock is always compromised [13,14]. The lactational performance of dairy cows and the total-tract apparent digestibility of all the nutrients significantly decreased when replacing the alfalfa hay (AH) with corn stover and RS as the main forage (30\% of DM diet) of isonitrogenous diets [14]. On the other hand, reducing the corn stover dosage to $19 \%$ of the dietary DM produced no significant differences in dry matter intake (DMI) and milk production [15]. Notably, similar milk yield and total-tract digestibility (TTD) were observed when the dairy cows were fed equivalent concentrations of neutral detergent fiber (NDF) from corn silage (CSil), AH, WS, and corn stover (50.8-101 g/kg of diet DM) [12]. Different forages vary in their digestibility of NDF, which is the most important trait in feed value determinations, and dominate the variability in total diet digestibility, helping in predicting DMI and lactating performance of dairy cows [16-18]. Meanwhile, forage is important in ruminant nutrition, not only as a source of ME but also contains sufficient physically effective neutral detergent fiber (peNDF) to stimulate rumination and saliva production, which buffers the rumen and promotes rumen health [19].

Digestibility is the most important trait in feed value determinations of forages [17]. The in situ nylon bag technique (ISNBT) and the mobile nylon bag technique (MNBT) are frequently used to predict the degradability and digestibility of nutrients and feeding value of feeds for animal production systems. The indigestible NDF ( $\left.\mathrm{iNDF}_{288}\right)$, determined by a $288 \mathrm{~h}$ ruminal in situ incubation, has been demonstrated to be a good predictor of forage digestibility and is an important parameter in mechanistic rumen models [17,19-22]. Formulating a diet to a specific level of NDF without reference to the iNDF could markedly affect its resulting intake, digestibility, and ME content [19]. Lippke et al. [23] suggested that maximum iNDF consumption is about $20 \mathrm{~g} / \mathrm{kgBW}^{0.75}$ per day. However, more research is required to resolve if this value is relevant for different production systems and different forages [19]. The Cornell Net Carbohydrate and Protein System (CNCPS) [24] and Cornell-Penn-Miner (CPM) Dairy [25] estimate the iNDF in forages using the formula $\mathrm{ADL} \times 2.4\left(\mathrm{iNDF}_{2.4}\right)$. However, tropical (C4) forages have large variations in iNDF and do vary in ruminal degradability. Total-tract NDF digestibility (TTNDFD), calculated 
as ruminal NDF digestion + hindgut NDF digestion, has recently been demonstrated to be a good predictor of forage digestibility [26,27]. A large number of studies have been conducted to investigate the ruminal degradability, iNDF, and total-tract digestibility (TTD) of concentrate feeds [20,28-41] and high-quality forages such as CSil [26,41-49], AH $[41,42,46,48-50]$, and oat hay [46,48] during the last two decades. However, studies on ruminal degradability, iNDF content, intestinal digestibility (ID), and TTD of the crop straws, especially CS, RS, and WS are limited. Sarnklong et al. gave an overview of the availability, nutritive quality, and possible strategies to improve the utilization of RS as a feed ingredient for ruminants [11].

Better assessment and awareness amongst nutritionists on the importance of iNDF in crop straws will improve the capacity of nutritionists to predict NDF digestibility and therefore most effectively develop balanced diets. Therefore, the objectives of this study were to (1) characterize the ruminal degradability, $\mathrm{iNDF}_{288}$ content, ID, and TTD of CP, $\mathrm{NDF}$, and ADF of three main crop straws (CS, RS, and WS) and (2) to compare these parameters with those of AH and CSil using the ISNBT and MNBT techniques.

\section{Materials and Methods}

Feeding and management of cows used in this study were according to the China Agriculture University animal research committee protocol (Protocol number: 2013-5-LZ). This experimental protocol was approved by the Institutional Animal Care and Use Committee of China Agricultural University (Protocol number: AW61110202-2; Date: 25 August 2019).

\subsection{Sample Preparations}

One sample for each of the forages was collected in the present study. CS, AH, and CSil samples were collected from Jinyindao dairy farm (Beijing, China), RS and WS were collected from Benniu (Harbin, China) and Huahuaniu (Zhengzhou, China) dairy farms, respectively. CSil and CS were selected as tropical (C4) forages, whereas, RS, WS, and AH belonged to subtropical (C3) forages. All forage samples were dried in an air oven at $65^{\circ} \mathrm{C}$ for $48 \mathrm{~h}$, then ground to pass through a $2.5 \mathrm{~mm}$ sieve. The chemical composition of the selected forage samples is shown in Table 1.

Table 1. Chemical composition and indigestible NDF of the forage samples ( $\mathrm{g} / \mathrm{kg}$ of DM, unless otherwise indicated).

\begin{tabular}{|c|c|c|c|c|c|}
\hline Item $^{1}$ & CS & RS & WS & AH & CSil \\
\hline $\mathrm{DM}$ (g/kg of fresh matter) & 911.13 & 929.65 & 919.97 & 911.23 & 316.23 \\
\hline $\mathrm{OM}$ & 915.73 & 875.03 & 902.17 & 896.47 & 944.83 \\
\hline $\mathrm{CP}$ & 55.23 & 43.73 & 44.37 & 203.90 & 89.87 \\
\hline NDICP (g/kg of CP) & 258.78 & 227.36 & 253.34 & 272.43 & 174.24 \\
\hline $\mathrm{ADICP}(\mathrm{g} / \mathrm{kg}$ of $\mathrm{CP})$ & 141.02 & 117.57 & 138.4 & 58.75 & 67.82 \\
\hline Starch & 27.84 & 23.80 & 22.93 & 11.50 & 309.37 \\
\hline Ether extract & 14.33 & 16.77 & 13.45 & 21.94 & 34.93 \\
\hline $\mathrm{NFC}^{2}$ & 109.70 & 99.76 & 29.67 & 230.50 & 339.36 \\
\hline NDF & 736.47 & 714.77 & 814.68 & 440.13 & 420.67 \\
\hline $\mathrm{ADF}$ & 431.31 & 454.90 & 514.19 & 316.10 & 246.23 \\
\hline Hemicellulose & 305.16 & 259.87 & 300.49 & 124.03 & 174.44 \\
\hline Cellulose & 376.86 & 390.52 & 442.72 & 246.52 & 214.78 \\
\hline $\mathrm{ADL}^{3}$ & 54.45 & 64.38 & 71.47 & 69.58 & 31.45 \\
\hline ADL (g/kg of NDF) & 73.93 & 90.07 & 87.73 & 158.09 & 74.76 \\
\hline $\mathrm{iNDF}_{2.4}{ }^{4}(\mathrm{~g} / \mathrm{kg}$ of NDF $)$ & 177.44 & 216.17 & 210.55 & 379.42 & 179.43 \\
\hline $\mathrm{iNDF}_{288}{ }^{5}(\mathrm{~g} / \mathrm{kg}$ of NDF) & 315.64 & 385.07 & 353.61 & 473.40 & 265.92 \\
\hline $\mathrm{iNDF}_{288} / \mathrm{ADL}^{6}$ & 4.27 & 4.28 & 4.03 & 2.99 & 3.56 \\
\hline
\end{tabular}

${ }^{1} \mathrm{CS}$, corn straw; RS, rice straw; WS, wheat straw; AH, alfalfa hay; Csil, corn silage; DM, dry matter; OM, organic matter; $\mathrm{CP}$, crude protein; NDICP, neutral detergent-insoluble crude protein; ADICP, acid detergent-insoluble crude protein; NFC, non-fiber carbohydrate; NDF, neutral detergent fiber; ADF, acid detergent fiber. ${ }^{2} \mathrm{NFC}(\mathrm{g} / \mathrm{kg}$ of DM $)=1000-(\mathrm{CP}+\mathrm{NDF}+\mathrm{EE}+\mathrm{Ash}) .{ }^{3}$ ADL: acid detergent lignin, determined by cellulose solubilization with sulphuric acid. ${ }^{4} \mathrm{iNDF}_{2.4}$, calculated as ADL $\left(\mathrm{g} / \mathrm{kg}\right.$ of NDF) $\times 2.4 .{ }^{5} \mathrm{iNDF}_{288}$, indigestible NDF determined by ruminal incubation for $288 \mathrm{~h}$ (Equation (5)). ${ }^{6} \mathrm{iNDF} / \mathrm{ADL}, \mathrm{iNDF}_{288}$ (g/kg of NDF)/ADL (g/kg of NDF). Values of chemical composition and $\mathrm{iNDF}_{2.4}$ represent the means of 3 parallel determinations or calculations, values of iNDF 288 represent the means of 6 replicates. 


\subsection{Cow Management}

Three second-parity lactating Holstein dairy cows (days in milk: $196.67 \pm 6.35 \mathrm{~d}$; dry matter intake: $23.68 \pm 0.88 \mathrm{~kg} / \mathrm{d}$; daily milk yield: $28.13 \pm 2.35 \mathrm{~kg} / \mathrm{d}$; body weight: $648 \pm 29 \mathrm{~kg}$ ) fitted with three-site (rumen, anterior duodenum, and terminal ileum)-cannula (10 cm internal diameter ruminal fistula; T-shaped intestinal fistula; Anscitech Farming Technology Co., Ltd., Wuhan, China) were used for the ruminal and intestinal incubation. Cows were milked and fed three times per day and allowed access to feed and fresh water ad libitum. The TMR diet ( $25.1 \%$ corn silage, $11.8 \%$ alfalfa hay, $2.0 \%$ oat hay, $61.1 \%$ concentrate mix; DM basis) with a measured nutrient composition of $25.8 \%$ starch, $17.1 \%$ CP, $29.7 \%$ NDF, and $4.9 \%$ ether extract was formulated to meet NRC requirements [51] of a dairy cow producing $31 \mathrm{~kg} / \mathrm{d}$ milk. Individual feed intake was measured during the study by a roughage intake control system (RIC, Zhenghong Co., Ltd., Shanghai, China).

\subsection{In Situ Ruminal Incubation and $\mathrm{NDF}_{288}$ Determination}

The in situ incubation procedure followed a proposal for a standardized method for forage ingredients $[51,52]$. Approximately $5 \mathrm{~g}$ of samples were filled into heat-sealed nylon bags $(8 \times 12 \mathrm{~cm}$ bag size; $50 \mu \mathrm{m}$ pore size; sample size to nylon bag surface was about $26 \mathrm{mg} / \mathrm{cm}^{2}$ calculated according to Diao et al. [53]) in six repetitions. Each cow was regarded as a replicate, each forage three replicates, and each forage had two parallel replicates per cow $(n=6)$. A maximum of six bags were attached to $50 \mathrm{~cm}$ semi-flexible stalks that retained bags within the liquid phase of the ruminal content. Five forages were incubated sequentially in different batches. A total of 270 bags ( 54 bags per forage) were prepared for in situ incubation. All bags were incubated at the same time of the day $(0730 \mathrm{~h})$ before the morning feeding and retrieved according to their respective incubation times. Two duplicated bags per forage were incubated in each cow and simultaneously retrieved at 0 (not incubated in the rumen), 6, 12, 16, 24, 36, 48, 72, and $288 \mathrm{~h}$ after incubation [22,51]. The forage samples were ruminally incubated for $12 \mathrm{~h}$ to determine the ruminal degradable $\mathrm{CP}(\mathrm{RDP}), 24 \mathrm{~h}$ for ruminal degradable $\mathrm{NDF}\left(\mathrm{RD}_{\mathrm{NDF}}\right)$ and $\mathrm{ADF}\left(\mathrm{RD}_{\mathrm{ADF}}\right)$ [47], and $288 \mathrm{~h}$ to determine $\mathrm{iNDF}_{288}[22,44,54]$. The NDF content in the $288 \mathrm{~h}$ residue is normally referred to as the truly indigestible NDF ( $\left.\mathrm{iNDF}_{288}\right)[17,20]$. Once retrieved from rumen at each time point, the bags were rinsed and manipulated in cold water until the water turned clear, then dried to a constant weight at $65^{\circ} \mathrm{C}$ for $48 \mathrm{~h}$. The dried residues were ground through a $1 \mathrm{~mm}$ sieve for further use.

\subsection{Pretreatment, Intestinal Incubation, and Total-Tract Digestibility Determination}

The mobile nylon bag incubation procedure followed the protocol proposed by Kaitho et al. [55]. In the present study, the rumen passage rate $(\mathrm{kp})$ for $\mathrm{CP}$ was calculated to be 4.18 according to the prediction models recommended by NRC (2001) [51]. The ruminal incubated residues ( $12 \mathrm{~h}$ for $\mathrm{CP}, 24 \mathrm{~h}$ for NDF and ADF) were ground through a $1 \mathrm{~mm}$ sieve and weighed at a rate of $0.5 \mathrm{~g}$ per mobile nylon bag $(3 \times 6 \mathrm{~cm}$ bag size; $25 \mu \mathrm{m}$ pore size) which was subsequently heat-sealed. Twelve duplicated bags per forage were placed in a shaking bath filled with pepsin $/ \mathrm{HCl}$ solution for $1 \mathrm{~h}$ at $39^{\circ} \mathrm{C}$ to simulate abomasal digestion before intestinal incubation. Pepsin $/ \mathrm{HCl}$ solution was prepared by dissolving $1 \mathrm{~g}$ of pepsin powder (activity 1:10,000, Beijing Aoboxing Biotech Co., Ltd., Beijing, China) in $1 \mathrm{~L}$ of $0.01 \mathrm{~mol} / \mathrm{L} \mathrm{HCl}$. The three Holstein cows fitted with three-site (rumen, anterior duodenum, and terminal ileum)-cannula were used for the intestinal incubation. Each cow was regarded as a replicate, each forage had three replicates, and each forage had 4 parallel replicates per cow $(n=12)$. Four bags of each forage were individually inserted in random order into the anterior duodenum cannula of each cow at a rate of two bags every 30 min starting from the morning feeding. A maximum of 12 bags can be inserted into the duodenum cannula per cow per day. Bags were collected in the feces from $8 \mathrm{~h}$ after incubation. The recovered bags were rinsed and manipulated in cold water until the water ran clear, then dried to a constant weight at $65{ }^{\circ} \mathrm{C}$ for $48 \mathrm{~h}$. Only bags recovered within $24 \mathrm{~h}$ after insertion were used for further analysis. 


\subsection{Chemical Analysis}

Forage samples and incubated residuals were dried in an air oven (DGG-9240B; Shanghai-ShenXin Inc, Shanghai, China) at $65{ }^{\circ} \mathrm{C}$ for $48 \mathrm{~h}$ to determine DM content. To ensure a homogeneous mixture, all samples were ground through a mill equipped with a $1 \mathrm{~mm}$ screen (KRT-34; KunJie, Beijing, China). Starch (method 996.11), nitrogen (method 984.13), ether extract (method 920.39), and ash (method 924.05) were determined according to the methods described by the Association of Official Analytical Chemists (AOAC) [56]. The contents of NDF and ADF were analyzed by the Ankom fiber analyzer (A2000i; Ankom Technology, Fairport, NY, USA) following the procedures of Van Soest et al. [57]. The content of acid detergent lignin (ADL) was determined by the solubilization of cellulose with $72 \%$ sulphuric acid. Hemicellulose and cellulose were then calculated as the differences between NDF and ADF, ADF, and ADL, respectively [51]. All forage samples and fermentation residues were conducted in triplicate.

\subsection{Calculations}

The degradation kinetics of $\mathrm{CP}, \mathrm{NDF}$, and ADF from nylon bags were calculated according to the following exponential equation [58]:

$$
\mathrm{y}=\mathrm{a}+\mathrm{b}\left(1-\mathrm{e}^{-\mathrm{ct}}\right)
$$

where $y$ is the ruminal degradation of DM, CP, NDF, and ADF at time $t$, $a$ is the rapidly degradable fraction $(\mathrm{g} / \mathrm{kg}) . \mathrm{b}$ is the potentially degradable fraction $(\mathrm{g} / \mathrm{kg})$, $\mathrm{c}$ is the constant rate of degradation of $b(\% / h)$, and $t$ is the time of incubation $(h)$. The calculated potential degradable fraction $(\mathrm{cpd}, \mathrm{g} / \mathrm{kg})$ was calculated as $\mathrm{a}+\mathrm{b}$.

The effective degradability (ED) of nutrients was calculated according to the following equation [58]:

$$
\mathrm{ED}=\mathrm{a}+\left(\frac{\mathrm{bc}}{\mathrm{c}+\mathrm{kp}}\right)
$$

where $a, b$, and $c$ are the same parameters represented in Equation (1) and $k(\% / h)$ is the rumen particle passage rate. The NRC (2001) [51] gives the rumen passage rate (kp) prediction equation for forage as follow:

$$
\mathrm{kp}=3.362+0.479 \times \mathrm{X}_{1}-0.007 \times \mathrm{X}_{2}-0.017 \times \mathrm{X}_{3}
$$

where $X_{1}, X_{2}$, and $X_{3}$ are dry matter intake ( $\%$ of body weight), percentage of concentrate in the diet DM, and percentage of NDF in DM, respectively. Therefore, the $\mathrm{kp}$ value of $4.18 \% / \mathrm{h}$ was calculated according to NRC (2001) (Equation (3)) [51] with dry matter intake of $23.68 \mathrm{~kg} / \mathrm{d}$, diet forage-to-concentrate ratio of $61.1: 38.9$, and NDF concentration of $29.7 \%$ in $\mathrm{DM}$ diet.

The indigestible neutral detergent fiber (iNDF) were determined by long-term $(288 \mathrm{~h})$ in situ ruminal incubation, and the iNDF content is calculated according to the following equation [17]:

$$
\mathrm{iNDF}_{288}(\mathrm{~g} / \mathrm{kg} \text { of NDF})=\left(\frac{\mathrm{NDF}_{288}}{\mathrm{NDF}}\right) \times 1000
$$

where $\mathrm{iNDF}_{288}(\mathrm{~g} / \mathrm{kg}$ of NDF) is the total indigestible NDF fraction of the forage NDF; $\mathrm{NDF}_{288}(\mathrm{~g} / \mathrm{kg})$ is the amount of NDF in the bag remaining after $288 \mathrm{~h}$ of ruminal incubation; $\mathrm{NDF}(\mathrm{g} / \mathrm{kg})$ is the amount of NDF in the bag before ruminal incubation. The determined potentially digestible NDF (dpdNDF) were measured according to the report of Rinne et al. [17] as follows:

$$
\mathrm{dpdNDF} \mathrm{N}_{288}=\mathrm{NDF}-\mathrm{iNDF}_{288}
$$

In the present study, the $\mathrm{dpdDM}_{288}, \mathrm{dpdCP_{288 }}$, and $\mathrm{dpd} \mathrm{ADF}_{288}$ were calculated according to the above-modified equation for $\mathrm{dpdNDF}_{288}$. The intestinal digestibility 
(Idg, \%) of ruminal undegradable nutrients in the residuals was calculated according to the following equation:

$$
\mathrm{Idg}=\frac{(\mathrm{C} 1 \times \mathrm{W} 1-\mathrm{C} 2 \times \mathrm{W} 2)}{\mathrm{C} 1 \times \mathrm{W} 1} \times 100
$$

where $\mathrm{C} 1, \mathrm{~W} 1, \mathrm{C} 2$, and $\mathrm{W} 2$ are the nutrients in the undegradable residue after $12 \mathrm{~h}(\mathrm{CP})$, $24 \mathrm{~h}$ (NDF and ADF) ruminal incubation $(\mathrm{g} / \mathrm{kg}$ ), the weight of undegradable residue placed into the mobile nylon bag for intestine incubation $(\mathrm{g})$, the nutrients content in the residue $(\mathrm{g} / \mathrm{kg})$, and the weight of intestinal undigestible residue $(\mathrm{g})$.

The intestinal digestible $\mathrm{CP}$ ( $\mathrm{ID}_{\mathrm{CP}}, \mathrm{g} / \mathrm{kg}$ of $\mathrm{CP}$ in initial forage) of ruminal undegradable $\mathrm{CP}$ was calculated using the following modified equation from the Dutch protein evaluation system DVE/OEB $2007[59,60]$ :

$$
\mathrm{ID}_{\mathrm{CP}}=\mathrm{CP} \times \frac{\mathrm{RUP}}{100} \times \frac{\mathrm{Idg}}{100}
$$

where $\mathrm{CP}(\mathrm{g} / \mathrm{kg})$ is the $\mathrm{CP}$ content in initial forage; $\mathrm{RUP}(\mathrm{g} / \mathrm{kg}$ of $\mathrm{CP})$ is the ruminal undegradable protein in incubated residue; and Idg (\%) is represented in Equation (7). RUP is the ruminal undegradable $\mathrm{CP}$ content after $12 \mathrm{~h}$ ruminal incubation. In the present study, the $\mathrm{ID}_{\mathrm{NDF}}$ and $\mathrm{ID}_{\mathrm{ADF}}$ were calculated according to the above-modified equation for $\mathrm{ID}_{\mathrm{CP}}$.

Total-tract neutral detergent fiber digestibility (TTNDFD; $\mathrm{g} / \mathrm{kg}$ of NDF) was calculated according to the study of Lopes et al. [26].

$$
\text { TTNDFD }=(\text { ruminal NDF degradation })+(\text { intestinal NDF digestion })
$$

where ruminal NDF degradation $(\mathrm{g} / \mathrm{kg}$ of NDF) is the ruminal degradable NDF content after $24 \mathrm{~h}$ incubation, intestinal NDF digestion ( $\mathrm{g} / \mathrm{kg}$ of NDF) is the intestinal digestible NDF content. In the present study, the TTD $\mathrm{CP}_{\text {and }} \mathrm{TTD}_{\mathrm{ADF}}$ were calculated according to the above-modified equation for TTNDFD.

\subsection{Statistical Analysis}

All data were analyzed using SAS (version 9.4, SAS Institute Inc., Cary, NC, USA). The ruminal degradation kinetics (i.e., $a, b, c, c p d$, dpd, and ED) of CP, NDF, and ADF within various forages were estimated using the NLIN procedure (Equations (1) and (2)). Data for ruminal degradability, intestinal digestibility, and total tract digestibility of $\mathrm{CP}, \mathrm{NDF}$, and ADF within various forages were summarized by descriptive statistics and analyzed using the MIXED procedure of SAS based on the following model:

$$
Y i j=\mu+F i+r j+\text { eij }
$$

where Yijk was the dependent variable, $\mu$ was the overall mean, Fi was the fixed effect of forage $(i=1-5)$, rj was the random effect of replicate $(j=1-6)$, and eij $=$ the residual error. Six replicates were used in the ruminal degradation experiment. Intestinal digestibility tests were conducted with 12 replicates for each forage. Statistical differences were considered significant at $p<0.05$. The simple linear regression equations were derived between the $\mathrm{dpd}_{288}$ (determined potential degradation fraction by $288 \mathrm{~h}$ ruminal incubation, Equation (5)) and cpd (calculated potential degradation fraction, Equation (1)). The multiple linear regression equations were estimated by the PROC CORR and REG procedures in SAS 9.4 to predict $\mathrm{iNDF}_{288}$ and TTD fractions from the chemical composition and ruminal degradation kinetics of different forages.

All figures were performed using GraphPad Prism (version 9.0.1, GraphPad, San Diego, CA, USA). Plotting and curve-fitting of data (Figure 1) were fitted to a one-phase association exponential model with three parameters: $\mathrm{y}=\mathrm{a}+\mathrm{b} \times[1-\exp (-\mathrm{c} \times \mathrm{t})]$ (Equation (1)) in GraphPad Prism. Data are expressed as means \pm standard deviation in the figure. Effects 
of forage type and incubation time onCP, NDF, and ADF degradability variables were analyzed using the MIXED procedure of SAS according to the following equation:

$$
\text { Yijk }=\mu+F i+r j+T j+\text { FTij }+ \text { eijk }
$$

where Yijk was the dependent variable, $\mu$ was the overall mean, Fi was the fixed effect of forage $(i=1-5)$, rj was the random effect of replicate $(j=1-6), T j$ was the incubation time effect $(j=1-9)$, FTij was the interaction between the forage types and incubation time, and eij was the residual error.
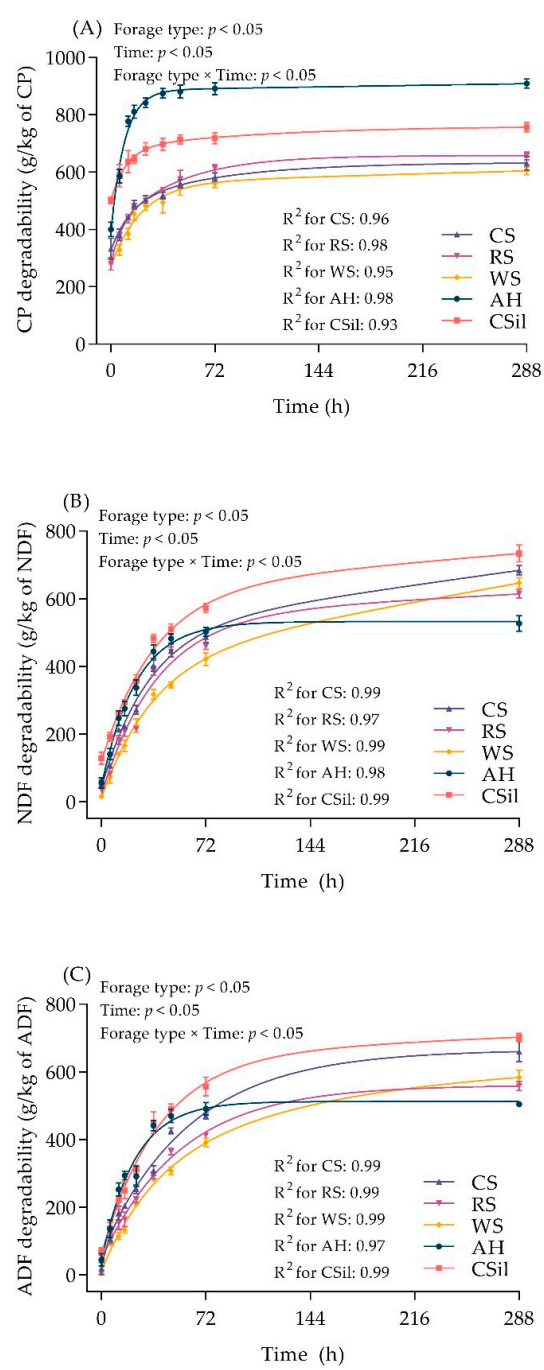

Figure 1. The real-time degradability of various forages during $288 \mathrm{~h}$ in situ incubation. (A) CP, (B) $\mathrm{NDF}$, and (C) ADF. Data are expressed as means \pm standard deviation. $p$-values of Forage Type, Time, and Forage Type $\times$ Time mean the effect of forage types, the effect of incubation times, and the interaction effect of forage types and incubation times. Data were fitted to a one-phase association exponential model with three parameters: $y=a+b \times[1-\exp (-c \times t)]$, where $y$ is the ruminal degradation of $\mathrm{CP}, \mathrm{NDF}$, and $\mathrm{ADF}$ at time $\mathrm{t}$, $\mathrm{a}$ is the soluble or rapidly degradable fraction $(\mathrm{g} / \mathrm{kg}) ; \mathrm{b}$ is the potentially degradable fraction $(\mathrm{g} / \mathrm{kg})$; $\mathrm{c}$ is the constant rate of degradation of $\mathrm{b}(\% / \mathrm{h}) ; \mathrm{t}$ is the time of incubation (h). Regression, $p<0.05 ; \mathrm{R}^{2}$ for CS, RS, WS, AH, and CSil $=0.93$ to 0.99 , as shown in the graph. CS, corn straw; RS, rice straw; WS, wheat straw; $\mathrm{AH}$, alfalfa hay; Csil, corn silage; DM, dry matter; $\mathrm{CP}$, crude protein; NDF, neutral detergent fiber; $\mathrm{ADF}$, acid detergent fiber. Each forage was incubated in 6 replicates (two for each time point per cow) in the rumen. 


\section{Results}

\subsection{In Situ Ruminal Degradability and $\mathrm{NDF}_{288}$}

The chemical compositions of the individual forage are listed in Table 1. Compared with AH and CSil, CS, RS, and WS had lower amounts of CP, ether extract, and NFC, and greater amounts of NDICP, ADICP, NDF, ADF, hemicellulose, and cellulose. The tropical (C4) forages (CS and CSil) had lower amounts of ADL (g/kg of DM), ADL (g/ $\mathrm{kg}$ of NDF), and $\mathrm{iNDF}_{2.4}(\mathrm{~g} / \mathrm{kg}$ of NDF) compared to those of subtropical (C3) forages (RS, WS, and $\mathrm{AH})$. AH had the highest $\mathrm{iNDF}_{2.4}$ and $\mathrm{iNDF}_{288}$ values of 379.42 and $473.40 \mathrm{~g} / \mathrm{kg}$ of NDF. CS and CSil had similar and lower iNDF 2.4 values of 177.44 and $179.43 \mathrm{~g} / \mathrm{kg}$ of NDF, while CSil had the lowest $\mathrm{iNDF}_{288}$ value of $265.92 \mathrm{~g} / \mathrm{kg}$ of NDF.

The real-time degradability of $\mathrm{CP}(\mathrm{A}), \mathrm{NDF}(\mathrm{B})$, and ADF (C) within various forages increased during $288 \mathrm{~h}$ in situ incubation (Figure 1), and the nonlinear model resulted in a high average coefficient of determination $\left(R^{2}>0.93\right)$ for all forages. There were significant differences in $\mathrm{CP}, \mathrm{NDF}$, and ADF degradability among the five forages during the entire $288 \mathrm{~h}$ incubation period ( $p$ value for the interaction effect of forage types and incubation times $<0.05)$. The CP degradability of CS, RS, and WS were lower than AH and Csil during the entire incubation period. Table 2 outlines ruminal degradation kinetics and effective degradability of $\mathrm{CP}, \mathrm{NDF}$, and $\mathrm{ADF}$ of various forages. CS, RS, and WS had lower a, cpd, $\mathrm{dpd}_{288}$, and ED of $\mathrm{CP}$ compared to AH and CSil $(p<0.05)$. The cpd and dpd of CSil were highest, with the CS, $\mathrm{RS}$, and WS being intermediate, and AH the lowest $(p<0.05)$. Lower ED of CP, NDF, and ADF was observed in CS, RS, and WS compared with AH and CSil $(p<0.05)$.

Table 2. In situ ruminal degradation kinetics and effective degradability of CP, NDF, and ADF in different forages ( $n=6)$.

\begin{tabular}{|c|c|c|c|c|c|c|c|}
\hline Item $^{1}$ & CS & RS & WS & AH & CSil & SEM $^{2}$ & $p$ Value \\
\hline \multicolumn{8}{|c|}{$\mathrm{CP}(\mathrm{g} / \mathrm{kg}$ of $\mathrm{CP}$, unless otherwise indicated $)$} \\
\hline$a^{3}$ & $332.91 \mathrm{bc}$ & $294.98^{\mathrm{cd}}$ & $270.04^{\mathrm{d}}$ & $364.25^{b}$ & $501.86^{\mathrm{a}}$ & 22.37 & $<0.05$ \\
\hline$b^{3}$ & $284.16^{\mathrm{cd}}$ & $344.21^{b}$ & $321.75 \mathrm{bc}$ & $529.95^{\mathrm{a}}$ & $231.92^{d}$ & 27.91 & $<0.05$ \\
\hline$c^{3}(\% / h)$ & $3.94^{\mathrm{c}}$ & $3.94^{\mathrm{c}}$ & $4.19^{\mathrm{c}}$ & $10.81^{\mathrm{a}}$ & $6.89^{b}$ & 0.80 & $<0.05$ \\
\hline $\operatorname{cpd}_{\mathrm{CP}}{ }^{3}$ & $617.08^{\mathrm{cd}}$ & $639.19^{c}$ & $591.80^{d}$ & $894.20^{a}$ & $733.78^{b}$ & 29.83 & $<0.05$ \\
\hline $\operatorname{dpd}_{\mathrm{CP} 288} 4$ & $631.53^{\mathrm{cd}}$ & $656.76^{c}$ & $604.98^{\mathrm{d}}$ & $909.72^{\mathrm{a}}$ & $757.06^{b}$ & 30.02 & $<0.05$ \\
\hline $\mathrm{ED}_{\mathrm{CP} 4.18}{ }^{5}$ & $466.24^{\mathrm{C}}$ & $461.69^{c}$ & $429.92^{\mathrm{d}}$ & $746.60^{\mathrm{a}}$ & $642.34^{b}$ & 33.14 & $<0.05$ \\
\hline \multicolumn{8}{|c|}{ NDF ( $\mathrm{g} / \mathrm{kg}$ of NDF, unless otherwise indicated) } \\
\hline$a^{3}$ & $53.09 \mathrm{~b}$ & $22.53^{\mathrm{c}}$ & $23.51^{\mathrm{c}}$ & $38.06^{c}$ & $123.06^{a}$ & 10.11 & $<0.05$ \\
\hline$b^{3}$ & $623.53^{a}$ & $587.52^{b}$ & $623.89^{a}$ & $493.23^{c}$ & $605.80^{a b}$ & 13.46 & $<0.05$ \\
\hline$c^{3}(\% / h)$ & $1.99^{b}$ & $2.27^{\mathrm{b}}$ & $1.57^{\mathrm{C}}$ & $4.31^{\mathrm{a}}$ & $2.15^{\mathrm{b}}$ & 0.26 & $<0.05$ \\
\hline $\operatorname{cpd}_{\mathrm{NDF}}{ }^{3}$ & $676.63^{b}$ & $610.05^{c}$ & $647.40^{b}$ & $531.28^{\mathrm{d}}$ & $728.85^{a}$ & 18.20 & $<0.05$ \\
\hline $\operatorname{dpd}_{\text {NDF288 }} 4$ & $684.36^{b}$ & $614.93^{c}$ & $646.39^{c}$ & $526.60^{d}$ & $734.08^{a}$ & 19.09 & $<0.05$ \\
\hline $\mathrm{ED}_{\mathrm{NDF} 4.18} 5$ & $253.83^{c}$ & $229.08^{d}$ & $193.54^{\mathrm{e}}$ & $288.31^{b}$ & $327.78^{a}$ & 12.54 & $<0.05$ \\
\hline \multicolumn{8}{|c|}{ ADF (g/kg of ADF, unless otherwise indicated) } \\
\hline$a^{3}$ & $37.40^{\mathrm{b}}$ & $24.67^{b}$ & $19.30^{b}$ & $32.58^{b}$ & $59.02^{\mathrm{a}}$ & 4.19 & $<0.05$ \\
\hline$b^{3}$ & $621.37^{a}$ & $530.65^{b}$ & $567.40^{b}$ & $478.73^{c}$ & $639.54^{a}$ & 16.64 & $<0.05$ \\
\hline$c^{3}(\% / h)$ & $1.82^{\mathrm{c}}$ & $2.01 \mathrm{bc}$ & $1.57^{\mathrm{c}}$ & $4.51^{\mathrm{a}}$ & $2.31^{\mathrm{b}}$ & 0.29 & $<0.05$ \\
\hline $\operatorname{cpd}_{\mathrm{ADF}}{ }^{3}$ & $658.78^{b}$ & $555.31^{c}$ & $586.70^{c}$ & $511.32^{\mathrm{e}}$ & $698.55^{a}$ & 18.81 & $<0.05$ \\
\hline $\operatorname{dpd}_{\mathrm{ADF} 288} 4$ & $660.06^{b}$ & $558.26^{c}$ & $583.39^{c}$ & $504.50^{\mathrm{d}}$ & $702.92^{\mathrm{a}}$ & 19.43 & $<0.05$ \\
\hline $\mathrm{ED}_{\mathrm{ADF} 4.18}{ }^{5}$ & $225.31^{b}$ & $196.57^{c}$ & $173.97^{\mathrm{d}}$ & $280.82^{a}$ & $286.22^{a}$ & 12.07 & $<0.05$ \\
\hline
\end{tabular}

a-e Means with different lowercase superscript letters within rows represent significant differences at $p$-value $<0.05 .{ }^{1} \mathrm{CS}$, corn straw; RS, rice straw; WS, wheat straw; AH, alfalfa hay; Csil, corn silage; DM, dry matter; CP, crude protein; NDF, neutral detergent fiber; ADF, acid detergent fiber. ${ }^{2}$ SEM, standard error of the mean. ${ }^{3} a$, the rapid degradable fraction; $b$, the slow degradable fraction; $c$, the constant rate of degradation of $b$ $(\% / \mathrm{h}) ; \mathrm{cpd}$, the calculated potential degradable fraction, calculated as $\mathrm{a}+\mathrm{b} .{ }^{4} \mathrm{dpd}$, the determined potential degradable fraction, the degradable fraction after $288 \mathrm{~h}$ ruminal incubation. ${ }^{5} \mathrm{ED}$, effective degradability, values with different capital subscript letters (CP, NDF, and ADF).

\subsection{Intestinal and Total-Tract Digestibility}

Intestinal digestible, and total-tract digested content of $\mathrm{CP}, \mathrm{NDF}$, and $\mathrm{ADF}$ in different forages are listed in Table 3. Compared with AH and CSil, CS, RS, and WS had lower totaltract digestibility of $\mathrm{CP}, \mathrm{NDF}$, and $\mathrm{ADF}(p<0.05)$, lower intestinal digestibility of rumen undegradable content of NDF $(p<0.05)$. Meanwhile, the tropical (C4) forages (CS and CSil) 


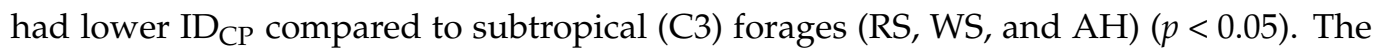
ruminal degradable, intestinal digestible, and total-tract undigested content of $\mathrm{CP}, \mathrm{NDF}$, and ADF for all the forages used in this experiment are shown in Figure 2. Larger amounts of $\mathrm{CP}$ were digested compared to NDF and ADF in the intestine.

Table 3. Ruminal degradable, intestinal digestible, and total-tract digested content of CP, NDF, and ADF in different forages $(n=12)$.

\begin{tabular}{|c|c|c|c|c|c|c|c|}
\hline Item $^{1}$ & CS & RS & WS & AH & Csil & SEM $^{2}$ & $p$ Value \\
\hline \multicolumn{8}{|c|}{$\mathrm{CP}(\mathrm{g} / \mathrm{kg}$ of $\mathrm{CP}$, unless otherwise indicated) } \\
\hline $\operatorname{RUD}_{\mathrm{CP}}{ }^{4}(12 \mathrm{~h})$ & $556.48^{b}$ & $562.72^{b}$ & $615.33^{a}$ & $221.82^{d}$ & $362.56^{c}$ & 39.94 & $<0.05$ \\
\hline Idg of $\mathrm{RUD}_{\mathrm{CP}}{ }^{5}(\%)$ & $29.75^{b}$ & $25.49^{b}$ & $25.19^{b}$ & $49.03^{\mathrm{a}}$ & $48.33^{\mathrm{a}}$ & 3.11 & $<0.05$ \\
\hline $\mathrm{ID}_{\mathrm{CP}} 6$ & $165.55^{a}$ & $141.57^{b}$ & $156.85^{a b}$ & $108.76^{c}$ & $175.22^{\mathrm{a}}$ & 6.56 & $<0.05$ \\
\hline $\mathrm{TTD}_{\mathrm{CP}}{ }^{7}$ & $609.08^{c}$ & $579.57^{d}$ & $541.52^{\mathrm{e}}$ & $886.94^{\mathrm{a}}$ & $812.67^{b}$ & 36.86 & $<0.05$ \\
\hline TTUD $_{\mathrm{CP}} 8$ & $390.92^{c}$ & $420.43^{b}$ & $458.48^{\mathrm{a}}$ & $113.06^{\mathrm{e}}$ & $187.33^{\mathrm{d}}$ & 36.86 & $<0.05$ \\
\hline \multicolumn{8}{|c|}{ NDF (g/kg of NDF, unless otherwise indicated) } \\
\hline $\mathrm{RUD}_{\mathrm{NDF}}{ }^{4}(24 \mathrm{~h})$ & $727.77^{\mathrm{b}}$ & $785.27^{\mathrm{a}}$ & $774.83^{\mathrm{a}}$ & $662.83^{c}$ & $643.55^{c}$ & 15.79 & $<0.05$ \\
\hline Idg of RUD $_{\mathrm{NDF}}{ }^{5}(\%)$ & $1.54^{\mathrm{b}}$ & $1.48^{b}$ & $1.63^{b}$ & $4.73^{\mathrm{a}}$ & $4.79^{\mathrm{a}}$ & 0.69 & $<0.05$ \\
\hline $\mathrm{ID}_{\mathrm{NDF}}{ }^{6}$ & $11.21^{\mathrm{b}}$ & $11.62^{b}$ & $12.63^{b}$ & $31.35^{\mathrm{a}}$ & $30.83^{\mathrm{a}}$ & 2.53 & $<0.05$ \\
\hline $\mathrm{TTD}_{\mathrm{NDF}}{ }^{7}$ & $283.44^{b}$ & $226.35^{c}$ & $237.8^{c}$ & $368.52^{\mathrm{a}}$ & $387.28^{a}$ & 18.06 & $<0.05$ \\
\hline TTUD $_{\text {NDF }} 8$ & $716.56^{b}$ & $773.65^{a}$ & $762.20^{\mathrm{a}}$ & $631.48^{c}$ & $612.72^{\mathrm{c}}$ & 18.06 & $<0.05$ \\
\hline \multicolumn{8}{|c|}{ ADF (g/kg of ADF, unless otherwise indicated) } \\
\hline $\mathrm{RUD}_{\mathrm{ADF}}{ }^{4}(24 \mathrm{~h})$ & $746.49^{b}$ & $776.72^{\mathrm{a}}$ & $790.88^{a}$ & $708.85^{c}$ & $688.65^{c}$ & 11.00 & $<0.05$ \\
\hline Idg of RUD $_{\mathrm{ADF}}{ }^{5}(\%)$ & 1.10 & 0.83 & -0.07 & 0.98 & 0.92 & 0.77 & 0.947 \\
\hline $\mathrm{ID}_{\mathrm{ADF}} 6$ & 8.21 & 6.45 & -0.55 & 6.95 & 6.34 & 0.71 & 0.938 \\
\hline $\mathrm{TTD}_{\mathrm{ADF}}{ }^{7}$ & $261.72^{b}$ & $229.73^{c}$ & $209.12^{c}$ & $298.10^{a}$ & $317.69^{a}$ & 11.38 & $<0.05$ \\
\hline TTUD $_{\mathrm{ADF}}{ }^{8}$ & $738.28^{b}$ & $770.27^{a}$ & $790.88^{a}$ & $701.90^{c}$ & $682.31^{c}$ & 11.38 & $<0.05$ \\
\hline
\end{tabular}

a-e Means with different lowercase superscript letters within rows represent the significant differences at $p$-value $<0.05 .{ }^{1} \mathrm{CS}$, corn straw; RS, rice straw; WS, wheat straw; AH, alfalfa hay; Csil, corn silage; DM, dry matter; CP, crude protein; NDF, neutral detergent fiber; ADF, acid detergent fiber. ${ }^{2}$ SEM, standard error of the mean. ${ }^{3} \mathrm{RD}$, ruminal degradable content which determined by ruminal incubation for $12 \mathrm{~h}(\mathrm{RDP})$ and $24 \mathrm{~h}\left(\mathrm{RD}_{\mathrm{NDF}}\right.$ and $\left.\mathrm{RD}_{\mathrm{ADF}}\right) .{ }^{4} \mathrm{RUD}$, ruminal degradable content which determined by ruminal incubation for $12 \mathrm{~h}(\mathrm{RUP})$ and $24 \mathrm{~h}\left(\mathrm{RUD}_{\mathrm{NDF}}\right.$ and $\left.\mathrm{RUD}_{\mathrm{ADF}}\right) .{ }^{5} \mathrm{Idg}(\%)$, intestinal tract digestibility of rumen undegradable content. ${ }^{6}$ ID, intestinal digestible content of rumen degradable content. ${ }^{7}$ TTD, total-tract digested content. ${ }^{8}$ TTUD, total-tract undigested content.
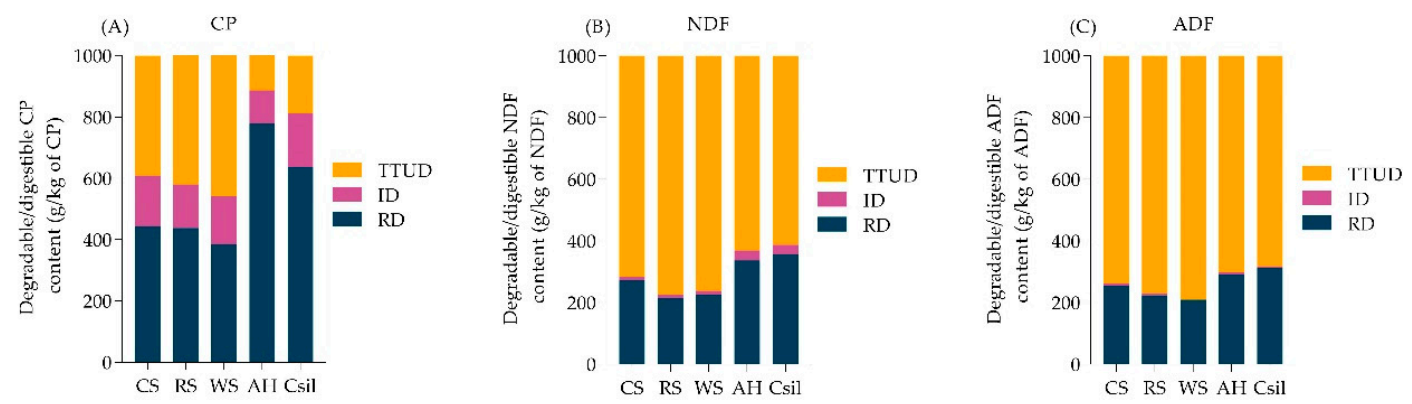

Figure 2. Ruminal degradable content, intestinal digestible content, and total-tract undigested content of CP, and NDF, and ADF in different forages. (A) CP, (B) NDF, and (C) ADF. RD, ruminal degradable content was determined after ruminal incubation for $12 \mathrm{~h}(\mathrm{CP})$ and $24 \mathrm{~h}$ (NDF and ADF); ID, intestinal digestible content; TTUD, total-tract undigested content. CS, corn straw; RS, rice straw; WS, wheat straw; AH, alfalfa hay; Csil, corn silage; DM, dry matter; CP, crude protein; NDF, neutral detergent fiber; ADF, acid detergent fiber. Each forage was incubated in 6 replicates (two for each time point per cow) in the rumen and 12 replicates for intestinal incubation.

\subsection{Prediction of $i N D F_{288}$ and Total-Tract Digestibility}

The multiple linear regression equations for the prediction of $\mathrm{iNDF}_{288}$ and TTD based on chemical composition and ruminal degradation kinetics are presented in Table 4. Regression analysis showed that the $\mathrm{iNDF}_{288}$ was influenced by the ADL ( $\mathrm{g} / \mathrm{kg}$ of NDF) content in the forage samples $\left(\mathrm{R}^{2}=0.995\right)$. TTD $\mathrm{NDF}$ and $\mathrm{TTD}_{\mathrm{ADF}}$ were jointly influenced 


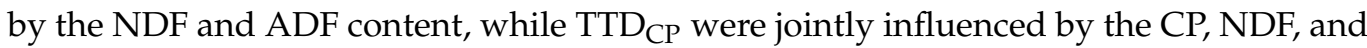
ADF content in the forage samples.

Table 4. The multiple linear regression equations for predicting $\mathrm{iNDF}_{288}$ and total-tract digestibility based on chemical composition and ruminal degradation kinetics of different forages $(n=5)$.

\begin{tabular}{|c|c|c|}
\hline Regression Equation ${ }^{1}$ & RMSE $^{2}$ & $\mathbf{R}^{2}$ Value $^{3}$ \\
\hline \multicolumn{3}{|l|}{$\mathrm{iNDF}_{288}$} \\
\hline $\mathrm{iNDF}_{288}=74.52+1.64 \mathrm{ADL}^{* *}+1.35 \mathrm{Ash}^{* *}$ & 7.51 & 0.995 \\
\hline $\mathrm{iNDF}_{288}=0.85 \mathrm{iNDF}_{2.4}^{* *}+162.07$ & 37.39 & 0.828 \\
\hline $\mathrm{dpd}_{\mathrm{NDF} 288}=1.05 \mathrm{cpd}_{\mathrm{NDF}} * *-30.01$ & 3.98 & 0.998 \\
\hline \multicolumn{3}{|l|}{ Total-tract digestibility (TTD) } \\
\hline $\mathrm{TTD}_{\mathrm{CP}}=922.67+1.13 \mathrm{CP}^{* *}-0.10 \mathrm{NDF}^{*}-0.68 \mathrm{ADF}^{* *}$ & 9.49 & 0.999 \\
\hline $\mathrm{TTD}_{\mathrm{NDF}}=554.41-0.10 \mathrm{NDF}^{*}-0.49 \mathrm{ADF} * *$ & 29.97 & 0.918 \\
\hline $\mathrm{TTD}_{\mathrm{ADF}}=424.19+0.06 \mathrm{NDF}^{*}-0.50 \mathrm{ADF}^{* *}$ & 12.38 & 0.963 \\
\hline
\end{tabular}

** represents the variables included in the multiple linear regressions were significant differences at $p$-value $<0.01$, * represents the significant differences at $p$-value $<0.05 ;{ }^{1} \mathrm{iNDF}_{288}$, indigestible NDF determined by ruminal incubation for $288 \mathrm{~h}$ (Equation (4)). ADL, acid detergent lignin ( $\mathrm{g} / \mathrm{kg}$ of NDF), determined by solubilization of cellulose with sulphuric acid. $\mathrm{iNDF}_{2.4}$, calculated as ADL $\left(\mathrm{g} / \mathrm{kg}\right.$ of NDF) $\times 2.4 . \mathrm{dpd}_{\mathrm{NDF} 288}$, the determined potential degradation NDF (g/kg of NDF), thedegradable NDF after $288 \mathrm{~h}$ ruminal incubation, $\mathrm{iNDF}_{288} \mathrm{Could}$ also be derived according to $\mathrm{NDF}-\mathrm{dpd}_{\mathrm{NDF} 288}$. $\mathrm{cpd}$, the calculated potential degradation fraction, calculated as $\mathrm{a}+\mathrm{b}$. TTD, total-tract digested content, calculated as ruminal degradable content + intestinal digestible content $\mathrm{CP}$, crude protein; NDF, neutral detergent fiber; ADF, acid detergent fiber. ${ }^{2} \mathrm{RMSE}$, root mean square error of intercepts in the linear regressions. $\mathrm{R}^{2}$ value (R-Squared), is a statistical measure of fit that indicates how much variation of a dependent variable is explained by the independent variables in a regression model.

\section{Discussions}

Digestibility in ruminants is affected by feed type, chemical composition, animal DM intake, healthy status, rumen bacteria [52,61,62]. Different forages vary in their chemical composition, resulting in different digestibility and the efficiency of energy utilization in dairy cows $[16,18,63]$. The digestibility and feed values of CS, RS, and WS were reported to be low due to their chemical composition, which may restrict their utilization by ruminants as a forage resource [11-13]. Wang et al. reported that corn stover and rice straw had lower amounts of CP (5.9 and 5.5 vs. 17.4 and $8.1 \%$ of DM) and NFC (11.6 and 5.2 vs. 22.4 and $14.6 \%$ of DM), as well as greater amounts of NDF (74.1 and 74.5 vs. 51.4 and $69.5 \%$ of DM) and ADF (39.7 and 45.5 vs. 37.0 and 34.0\% of DM), compared to AH and CSil [14]. Sarnklong et al. published the mean values of $\mathrm{N}$ content, NDF, ADF, hemicellulose, cellulose, and ADL of rice straw as $0.96,73.01,41.59,31.42$, and $4.84 \%$ of DM, respectively [11]. Consistently, the CS, RS, and WS in the current study had lower amounts of CP and NFC, and greater NDF, ADF, hemicellulose, and cellulose contents compared to those of AH and CSil. Meanwhile, the contents of NDF (420.67 g/ $\mathrm{kg}$ of DM) and ADF (246.23 g/ $\mathrm{kg}$ of DM) of Csil in the current study were lower compared to the results published by Wang et al. [14], which might be due to the differences in the stage of maturity and the grain content.

The rates of pdNDF degradation and effective degradability of NDF for AH and CSil in the present study were consistent with those from previous studies $[18,43,49]$. The constant rate of degradation of pdNDF and ED of NDF for CSil $(n=74)$ ranged from 1.23 to $3.17 \% / \mathrm{h}$ and from 36.5 to $61.4 \%$, respectively [43]. Rates of pdNDF digestion ranged from 0.0426 to $0.0569 / \mathrm{h}$ and from 0.1402 to $0.0515 / \mathrm{h}$ for maize silage $(n=17)$ and Lucerne $(n=10)$, respectively [18] The $\mathrm{CP}$ content in forage has been reported to be the most limiting nutrient parameter when the $\mathrm{CP}$ was below the lowest threshold level (8.0\%) [64]. The natural pasture hay had very low $\mathrm{CP}$ content $(38.8 \mathrm{~g} / \mathrm{kg} \mathrm{DM})$, which was below the $\mathrm{CP}$ requirements for ruminant animals for proper rumen function and efficient microbial activity [64,65]. Unsurprisingly, the CP, NDF, and ADF degradability of CS, RS, and WS were lower than those of AH and Csil during the first $48 \mathrm{~h}$ of incubation, implying the low nutritional value of crop straws. A 1-percentage-unit change in NDF digestibility (NDFD) has been correlated with a $0.17 \mathrm{~kg}$ increase in voluntary DMI and a $0.25 \mathrm{~kg}$ increase in $4 \%$ FCM yield [16]. However, the NDF and ADF degradability of the crop straws exceeded those of $\mathrm{AH}$ at $288 \mathrm{~h}$ of incubation, indicating that crop straws have a larger amount of potential degradation fraction. 
The iNDF has been demonstrated to be a good predictor of forage digestibility and is an important parameter in mechanistic rumen models [17,19-22]. The CNCPS [24] and CPM Dairy [25] had previously used a factor $\mathrm{iNDF}_{2.4}$ to describe the iNDF of forages. It should be noted that the tropical (C4) forages (CS and CSil) had lower amounts of ADL and $\mathrm{iNDF}_{2.4}$ compared to those of subtropical (C3) forages (RS, WS, and AH). Furthermore, it is remarkable that $\mathrm{AH}$ had the highest $\mathrm{iNDF}_{2.4}$ and $\mathrm{iNDF}_{288}$ values (379.42 and $473.40 \mathrm{~g} / \mathrm{kg}$ of NDF), and CSil had the lowest iNDF 288 value $(265.92 \mathrm{~g} / \mathrm{kg}$ of NDF) in the present study. Consistently, Raffrenato et al. analyzed more than two hundred samples of several forage species from Australia and South Africa; the results indicated that the lignin and iNDF were highest in legumes and C3 forages on NDF basis [48]. These observations already demonstrate how the plant species and growing conditions play an important role in determining the chemical and structural relationship between the indigestible cell wall components and iNDF content. Therefore, ADL seems to have a more negative effect in determining iNDF in forages. The iNDF/ADL ratios in the present study were 4.27, 4.28, 4.03, 2.99, and 3.56 for CS, RS, WS, AH, and CSil, respectively. While AH resulted in ratios closer to 2.4, and different environmental conditions caused higher ratios for alfalfa samples, other forages averaged around 4 during the same time $[48,49,66]$, which was consistent with the present study. These observations demonstrate that the value of 2.4 cannot be valid among all forages, and it represents higher values for $\mathrm{iNDF}_{288}$ compared to $\mathrm{iNDF}_{2.4}$ across all forage samples. Using $\mathrm{iNDF}_{240}$ (ruminal incubation for $240 \mathrm{~h}$ ) showed consistently lower ME between 2 and $10 \mathrm{MJ} /$ day, compared to when using $\mathrm{iNDF}_{2.4}$. As a consequence, the improved metabolizable protein and ME values would result in 0.3 to $3.2 \mathrm{~kg} / \mathrm{d}$ less (10\% reduction) milk, compared to when using iNDF2.4 [49].

TTD has been demonstrated to be a good predictor of feed digestibility [27]. The intestinal digestible CP among all forages in the present study ranged from 108.76-175.22 $\mathrm{g} / \mathrm{kg}$ of CP. Similar results in sub-irrigated meadow and upland native range grass were reported by Buckner et al. [67]. However, higher intestinal digestible CP with average values of 0.353 in maize silages and 0.237 in grass silages were reported by Ali et al. [47]. This might be due to differences in forage species, forage CP content, and the ruminal degradable fraction in the two studies. TTD of CP, NDF, and ADF in the present study were $541.52-886.94 \mathrm{~g} / \mathrm{kg}$ of CP, 226.35-387.28 g/ kg of NDF, and 209.12-317.69 $\mathrm{g} / \mathrm{kg}$ of ADF, respectively. The contribution in the post ruminal digestion of the TTNDFD is low, as cows do not secrete enzymes with fibrinolytic activity; rumen undegradable NDF and ADF cannot be digested in the small intestines, but might make up 0 to 0.20 of TTNDFD fermented in the hindgut [47]. Therefore, a longer ruminal incubation period would result in a greater amount of TTNDFD. Nevertheless, similar TTNDFD results of Csil and AH were reported in previous studies $[26,47,68]$. Lower TTNDFD in crop straws were determined in the current study, as the crop straws consist predominantly of the cell wall, which is made up of cellulose, hemicellulose, and lignin.

The regression equations showed that the $\mathrm{iNDF}_{288}$ and TTD were influenced by the chemical composition of forages, especially ADL, NDF, ADF, ash, and CP. Although only five forages were included in the equation, a general regression equation with a satisfactory accuracy $\left(\mathrm{R}^{2}=0.995 ; \mathrm{RMSE}=7.51 \mathrm{~g} / \mathrm{kg}\right.$ of NDF) was derived for the prediction of $\mathrm{iNDF}_{288}$ based on ADL and ash contents of forages. Contrarily, Raffrenato et al. analyzed more than two hundred samples of several forage species from Australia and South Africa, and similar equations for the prediction of iNDF were determined [48]. Lopes et al. noted that a good model to predict TTNDFD should consider more parameters, such as iNDF, pdNDF and $\mathrm{kp}$ [68]. High accuracies of regression equations $\left(\mathrm{R}^{2} \geq 0.918\right)$ for TTD prediction were generated based on NDF, ADF, and CP content of forages. A more accurate and precise estimation of iNDF and TTD would significantly improve the fine-tuning of dairy cow diets, especially when using high forage and/or NDF rations.

\section{Conclusions}

Generally, CS, RS, and WS had lower nutritional values compared to AH and Csil. However, CS, RS, and WS had higher ruminal potential NDF degradation, intestinal 
digestible $\mathrm{CP}$, and lower $\mathrm{iNDF}_{288}$ content compared to $\mathrm{AH}$. Incorporating this information into rations could improve our ability to optimize the utilization of main crop straws and milk production. Equations based on chemical compositions and ruminal degradation kinetics can give acceptable estimates of $\mathrm{NDF}_{288}$ and TTD.

Author Contributions: Conceptualization, S.L. and W.W.; methodology, Y.W., Z.C. and H.Y.; software, E.W.; validation, S.L.; formal analysis, E.W.; investigation, E.W., J.W. and X.S.; resources, F.K. and S.W.; data curation, E.W.; writing—original draft preparation, E.W.; writing-review and editing, J.L., J.W. and W.W.; visualization, E.W.; supervision, S.L.; project administration, W.W.; funding acquisition, S.L. and W.W. All authors have read and agreed to the published version of the manuscript.

Funding: This research was funded by "China Agriculture Research System of MOF and MARA" and "The 2115 Talent Development Program of China Agricultural University".

Institutional Review Board Statement: The study was conducted according to the guidelines of the Declaration of Helsinki, and approved by the Institutional Animal Care and Use Committee of China Agricultural University (Protocol number: AW61110202-2; Date: 25 August 2019).

Acknowledgments: We would like to thank the staffs from Beijing Sunlon livestock Development Co., Ltd. for assistance with feeding and management of the fistula cows.

Conflicts of Interest: The authors declare no conflict of interest.

\section{References}

1. Statista, Worldwide Production of Grain in 2020/21, by Type. Available online: https:/ /www.statista.com/statistics/263977/worldgrain-production-by-type/ (accessed on 10 August 2021).

2. Li, H.; Cao, Y.; Wang, X.; Ge, X.; Li, B.; Jin, C. Evaluation on the Production of Food Crop Straw in China from 2006 to 2014 . Bioenerg. Res. 2017, 10, 949-957. [CrossRef]

3. Ren, J.; Yu, P.; Xu, X. Straw Utilization in China-Status and Recommendations. Sustainability 2019, 11, 1762. [CrossRef]

4. Li, J.; Wei, L.; Duan, Q.; Hu, G.; Zhang, G. Semi-Continuous Anaerobic Co-Digestion of Dairy Manure with Three Crop Residues for Biogas Production. Bioresour. Technol. 2014, 156, 307-313. [CrossRef] [PubMed]

5. Wang, Y.; Bi, Y.; Gao, C. The Assessment and Utilization of Straw Resources in China. Agric. Sci. China 2010, 9, 1807-1815. [CrossRef]

6. Weimer, P.J.; Russell, J.B.; Muck, R.E. Lessons from the Cow: What the Ruminant Animal Can Teach Us About Consolidated Bioprocessing of Cellulosic Biomass. Bioresour. Technol. 2009, 100, 5323-5331. [CrossRef] [PubMed]

7. Seshadri, R.; Leahy, S.C.; Attwood, G.T.; Teh, K.H.; Lambie, S.C.; Cookson, A.L.; Eloe-Fadrosh, E.A.; Pavlopoulos, G.A.; Hadjithomas, M.; Varghese, N.J.; et al. Cultivation and Sequencing of Rumen Microbiome Members from the Hungate1000 Collection. Nat. Biotechnol. 2018, 36, 359-367. [CrossRef]

8. Firkins, J.L.; Yu, Z. Ruminant Nutrition Symposium: How to Use Data on the Rumen Microbiome to Improve Our Understanding of Ruminant Nutrition. J. Anim. Sci. 2015, 93, 1450-1470. [CrossRef]

9. Herrero, M.; Havlík, P.; Valin, H.; Notenbaert, A.; Rufino, M.C.; Thornton, P.K.; Blümmel, M.; Weiss, F.; Grace, D.; Obersteiner, M. Biomass Use, Production, Feed Efficiencies, and Greenhouse Gas Emissions from Global Livestock Systems. Proc. Natl. Acad. Sci. USA 2013, 110, 20888-20893. [CrossRef] [PubMed]

10. Reisinger, A.; Clark, H. How Much Do Direct Livestock Emissions Actually Contribute to Global Warming? Glob. Chang. Biol. 2018, 24, 1749-1761. [CrossRef] [PubMed]

11. Sarnklong, C.; Cone, J.W.; Pellikaan, W.; Hendriks, W.H. Utilization of Rice Straw and Different Treatments to Improve Its Feed Value for Ruminants: A Review. Asian Australas. J. Anim. Sci. 2010, 23, 680-692. [CrossRef]

12. Eastridge, M.L.; Starkey, R.A.; Gott, P.N.; Oelker, E.R.; Sewell, A.R.; Mathew, B.; Firkins, J.L. Dairy Cows Fed Equivalent Concentrations of Forage Neutral Detergent Fiber from Corn Silage, Alfalfa Hay, Wheat Straw, and Corn Stover Had Similar Milk Yield and Total Tract Digestibility. Anim. Feed Sci. Technol. 2017, 225, 81-86. [CrossRef]

13. Getahun, K.Y. Effect of Wheat Straw Urea Treatment and Leucaena Leucocephala Foliage Hay Supplementation on Intake, Digestibility, Nitrogen Balance and Growth of Lambs. Int. J. Livest. Prod. 2014, 5, 88-96. [CrossRef]

14. Wang, B.; Mao, S.Y.; Yang, H.J.; Wu, Y.M.; Wang, J.K.; Li, S.L.; Shen, Z.M.; Liu, J.X. Effects of Alfalfa and Cereal Straw as a Forage Source on Nutrient Digestibility and Lactation Performance in Lactating Dairy Cows. J. Dairy Sci. 2014, 97, 7706-7715. [CrossRef] [PubMed]

15. Zhu, W.; Fu, Y.; Wang, B.; Wang, C.; Ye, J.A.; Wu, Y.M.; Liu, J.X. Effects of Dietary Forage Sources on Rumen Microbial Protein Synthesis and Milk Performance in Early Lactating Dairy Cows. J. Dairy Sci. 2013, 96, 1727-1734. [CrossRef] [PubMed]

16. Oba, M.; Allen, M.S. Evaluation of the Importance of the Digestibility of Neutral Detergent Fiber from Forage: Effects on Dry Matter Intake and Milk Yield of Dairy Cows. J. Dairy Sci. 1999, 82, 589-596. [CrossRef] 
17. Huhtanen, P.; Nousiainen, J.; Rinne, M. Recent Developments in Forage Evaluation with Special Reference to Practical Applications. Agr. Food Sci. 2006, 15, 293-323. [CrossRef]

18. Nousiainen, J.; Rinne, M.; Huhtanen, P. A Meta-Analysis of Feed Digestion in Dairy Cows. 1. The Effects of Forage and Concentrate Factors on Total Diet Digestibility. J. Dairy Sci. 2009, 92, 5019-5030. [CrossRef]

19. Harper, K.; McNeill, D. The Role Indf in the Regulation of Feed Intake and the Importance of Its Assessment in Subtropical Ruminant Systems (the Role of Indf in the Regulation of Forage Intake). Agriculture 2015, 5, 778-790. [CrossRef]

20. Karisson, L.; Ruiz-Moreno, M.; Stern, M.D.; Martinsson, K. Effects of Temperature During Moist Heat Treatment on Ruminal Degradability and Intestinal Digestibility of Protein and Amino Acids in Hempseed Cake. Asian Australas. J. Anim. Sci. 2012, 25, 1559-1567. [CrossRef]

21. Nousiainen, J.; Rinne, M.; Hellämäki, M.; Huhtanen, P. Prediction of the Digestibility of Primary Growth and Regrowth Grass Silages from Chemical Composition, Pepsin-Cellulase Solubility and Indigestible Cell Wall Content. Anim. Feed Sci. Technol. 2003, 110, 61-74. [CrossRef]

22. Krizsan, S.J.; Rinne, M.; Nyholm, L.; Huhtanen, P. New Recommendations for the Ruminal in Situ Determination of Indigestible Neutral Detergent Fibre. Anim. Feed Sci. Technol. 2015, 205, 31-41. [CrossRef]

23. Lippke, H. Regulation of Voluntary Intake of Ryegrass and Sorghum Forages in Cattle by Indigestible Neutral Detergent Fiber. J. Anim. Sci. 1986, 63, 1459-1468. [CrossRef]

24. Tylutki, T.P.; Fox, D.G.; Durbal, V.M.; Tedeschi, L.O.; Russell, J.B.; Van Amburgh, M.E.; Overton, T.R.; Chase, L.E.; Pell, A.N. Cornell Net Carbohydrate and Protein System: A Model for Precision Feeding of Dairy Cattle. Anim. Feed Sci. Technol. 2008, 143, 174-202. [CrossRef]

25. Tedeschi, L.O.; Chalupa, W.; Janczewski, E.; Fox, D.G.; Sniffen, C.; Munson, R.; Kononoff, P.J.; Boston, R. Evaluation and Application of the Cpm Dairy Nutrition Model. J. Agric. Sci. 2007, 146, 171-182. [CrossRef]

26. Lopes, F.; Cook, D.E.; Combs, D.K. Validation of an in Vitro Model for Predicting Rumen and Total-Tract Fiber Digestibility in Dairy Cows Fed Corn Silages with Different in Vitro Neutral Detergent Fiber Digestibilities at 2 Levels of Dry Matter Intake. J. Dairy Sci. 2015, 98, 574-585. [CrossRef]

27. Weld, K.A.; Armentano, L.E. The Effects of Adding Fat to Diets of Lactating Dairy Cows on Total-Tract Neutral Detergent Fiber Digestibility: A Meta-Analysis. J. Dairy Sci. 2017, 100, 1766-1779. [CrossRef]

28. Shirmohammadi, S.; Taghizadeh, A.; Hosseinkhani, A.; Moghaddam, G.A.; Salem, A.Z.M.; Barbabosa Pliego, A. Ruminal and Post-Ruminal Barley Grain Digestion and Starch Granule Morphology under Three Heat Methods. Ann. Appl. Biol. 2021, 178, 508-518. [CrossRef]

29. Krogstad, K.C.; Anderson, J.L.; Herrick, K.J. In Situ Rumen Dry Matter, Neutral Detergent Fiber, and Crude Protein Degradability in Dairy Cows and in Vitro Intestinal Digestibility of Dried Distillers Grains with Solubles with Varying Fat Concentrations. Appl. Anim. Sci. 2020, 36, 503-508. [CrossRef]

30. Xu, H.; Li, X.; Me, E.; Zheng, J.; Zhao, H.; Zhang, Y. Study on the Relationship between Nutritional Value, Ruminal Degradation Characteristics and Molecular Structure of Protein in Different Heat-Treated Ddgs. Chin. J. Anim. Sci. 2019, 55, 73-80.

31. Nedelkov, K.V. In Situ Evaluation of Ruminal Degradability and Intestinal Digestibility of Sunflower Meal Compared to Soybean Meal. Iran. J. Appl. Sci. 2019, 9, 395-400.

32. Nasehi, M.; Torbatinejad, N.M.; Rezaie, M.; Ghoorchi, T. The Effect of Green Tea Waste Extract on Ruminal Degradability and Intestinal Digestibility of Barley Grain. Turk. J. Vet. Anim. Sci. 2018, 42, 624-632. [CrossRef]

33. Fu, L.; Ma, T.; Diao, Q.; Cheng, S.; Sun, Z.; Li, C. Correlation Analysis of Ruminal Degradation Characteristics and in Vitro Small Intestinal Digestibility of Rumen Undegraded Protein of Common Concentrates for Mutton Sheep. Chin. J. Anim. Nrti. 2018, 30, 2641-2651.

34. Barchiesi, C.; Williams, P.; Velasquez, A. Lupin and Pea Extrusion Decreases the Ruminal Degradability and Improves the True Ileal Digestibility of Crude Protein. Cienc. Investig. Agrar. 2018, 45, 231-239. [CrossRef]

35. Zhao, Y.; Yan, S.; He, Z.; Anele, U.Y.; Swift, M.L.; McAllister, T.A.; Yang, W. Effect of Starch Content and Processing Method on in Situ Ruminal and in Vitro Intestinal Digestion of Barley Grain in Beef Heifers. Anim. Feed Sci. Technol. 2016, 216, 121-128. [CrossRef]

36. Vasconcelos, A.M.d.; Dias, M.; Nascimento, V.A.; Rogerio, M.C.P.; Facanha, D.A.E. Ruminal Degradability and Intestinal Digestibility of Raw and Roasted Soy Beans in Dairy Cows. Rev. Bras. De Saúde E Produção Anim. 2016, 17, 744-752. [CrossRef]

37. Wulandari, W.; Widyobroto, B.P.; Noviandi, C.T.; Agus, A. The Effect of Soybean Meal Heating Time on the in Vitro Digestibility and Ruminal Fermentation Profile. Iran. J. Appl. Sci. 2020, 10, 595-601.

38. Gao, W.; Chen, A.; Zhang, B.; Kong, P.; Liu, C.; Zhao, J. Rumen Degradability and Post-Ruminal Digestion of Dry Matter, Nitrogen and Amino Acids of Three Protein Supplements. Asian Australas. J. Anim. Sci. 2015, 28, 485-493. [CrossRef] [PubMed]

39. Philippeau, C.; Varloud, M.; Julliand, V. Mobile Bag Starch Prececal Disappearance and Postprandial Glycemic Response of Four Forms of Barley in Horses. J. Anim. Sci. 2014, 92, 2087-2093. [CrossRef] [PubMed]

40. Paz, H.A.; Klopfenstein, T.J.; Hostetler, D.; Fernando, S.C.; Castillo-Lopez, E.; Kononoff, P.J. Ruminal Degradation and Intestinal Digestibility of Protein and Amino Acids in High-Protein Feedstuffs Commonly Used in Dairy Diets. J. Dairy Sci. 2014, 97, 6485-6498. [CrossRef]

41. Krizsan, S.J.; Huhtanen, P. Effect of Diet Composition and Incubation Time on Feed Indigestible Neutral Detergent Fiber Concentration in Dairy Cows. J. Dairy Sci. 2013, 96, 1715-1726. [CrossRef] [PubMed] 
42. Raffrenato, E.; Nicholson, C.F.; Van Amburgh, M.E. Development of a Mathematical Model to Predict Pool Sizes and Rates of Digestion of 2 Pools of Digestible Neutral Detergent Fiber and an Undigested Neutral Detergent Fiber Fraction within Various Forages. J. Dairy Sci. 2019, 102, 351-364. [CrossRef]

43. Hristov, A.N.; Harper, M.T.; Roth, G.; Canale, C.; Huhtanen, P.; Richard, T.L.; DiMarco, K. Effects of Ensiling Time on Corn Silage Neutral Detergent Fiber Degradability and Relationship between Laboratory Fiber Analyses and in Vivo Digestibility. J. Dairy Sci. 2020, 103, 2333-2346. [CrossRef]

44. Bender, R.W.; Cook, D.E.; Combs, D.K. Comparison of in Situ Versus in Vitro Methods of Fiber Digestion at 120 and 288 Hours to Quantify the Indigestible Neutral Detergent Fiber Fraction of Corn Silage Samples. J. Dairy Sci. 2016, 99, 5394-5400. [CrossRef] [PubMed]

45. Lopes, F.; Cook, D.E.; Combs, D.K. Effects of Varying Dietary Ratios of Corn Silage to Alfalfa Silage on Digestion of Neutral Detergent Fiber in Lactating Dairy Cows. J. Dairy Sci. 2015, 98, 6291-6303. [CrossRef]

46. Edmunds, B.; Südekum, K.H.; Spiekers, H.; Schwarz, F.J. Estimating Ruminal Crude Protein Degradation of Forages Using in Situ and in Vitro Techniques. Anim. Feed Sci. Technol. 2012, 175, 95-105. [CrossRef]

47. Ali, M.; Weisbjerg, M.R.; Cone, J.W.; van Duinkerken, G.; Blok, M.C.; Bruinenberg, M.; Hendriks, W.H. Postruminal Degradation of Crude Protein, Neutral Detergent Fibre and Starch of Maize and Grass Silages in Dairy Cows. Anim. Feed Sci. Technol. 2012, 177, 172-179. [CrossRef]

48. Raffrenato, E.; Lombard, R.; Erasmus, L.J.; McNeill, D.M.; Barber, D.; Callow, M.; Poppi, D.P. Prediction of Indigestible Ndf in South African and Australian Forages from Cell Wall Characteristics. Anim. Feed. Sci. Technol. 2018, 246, 104-113. [CrossRef]

49. Raffrenato, E.; Erasmus, L.J. Variability of Indigestible Ndf in C3 and C4 Forages and Implications on the Resulting Feed Energy Values and Potential Microbial Protein Synthesis in Dairy Cattle. S. Afr. J. Anim. Sci. 2014, 43, 98. [CrossRef]

50. Zhang, G.J.; Wang, Y.; Yan, Y.H.; Hall, M.H.; Undersander, D.J.; Combs, D.K. Comparison of Two in Situ Reference Methods to Estimate Indigestible Ndf by near Infrared Reflectance Spectroscopy in Alfalfa. Heliyon 2021, 7, e07313. [CrossRef] [PubMed]

51. NRC. Nutrient Requirements of Dairy Cattle, 7th ed.; National Academic Press: Washington, DC, USA, 2001.

52. Nocek, J.E. In Situ and Other Methods to Estimate Ruminal Protein and Energy Digestibility: A Review. J. Dairy Sci. 1988, 71, 2051-2069. [CrossRef]

53. Diao, X.; Dang, S.; Liu, S.; Jing, L.; Wang, Y.; Zhang, W. Determination of the Appropriate Ratio of Sample Size to Nylon Bag Area for in Situ Nylon Bag Technique Evaluation of Rumen Digestibility of Feedstuffs in Sheep. Livest. Sci. 2020, 241, 104254. [CrossRef]

54. Volden, H. Norfor-the Nordic Feed Evaluation System; Wageningen Academic Publishers: Wageningen, The Netherlands, 2011.

55. Kaitho, R.J.; Umunna, N.N.; Nsahlai, I.V.; Tamminga, S.; van Bruchem, J. Nitrogen in Browse Species: Ruminal Degradability and Post-Ruminal Digestibility Measured by Mobile Nylon Bag and in Vitro Techniques. J. Sci. Food Agric. 1998, 76, 488-498. [CrossRef]

56. Association of Official Analytical Chemists (AOAC). Official Methods of Analysis, 16th ed.; AOAC International: Washington, DC, USA, 1995.

57. Vansoest, P.J.; Robertson, J.B.; Lewis, B.A. Methods for Dietary Fiber, Neutral Detergent Fiber, and Nonstarch Polysaccharides in Relation to Animal Nutrition. J. Dairy Sci. 1991, 74, 3583-3597. [CrossRef]

58. Ørskov, E.R.; McDonald, I. The Estimation of Protein Degradability in the Rumen from Incubation Measurements Weighted According to Rate of Passage. J. Agric. Sci. 2009, 92, 499-503. [CrossRef]

59. Van Duinkerken, G.; Blok, M.C.; Bannink, A.; Cone, J.W.; Dijkstra, J.; Van Vuuren, A.M.; Tamminga, S. Update of the Dutch Protein Evaluation System for Ruminants: The Dve/Oeb2010 System. J. Agric. Sci. 2010, 149, 351-367. [CrossRef]

60. Tamminga, S.; Brandsma, G.G.; Van Duinkerken, G.; Van Vuuren, A.M.; Blok, M.C. Protein Evaluation for Ruminants: The DVE/OEB 2007-System; CVB Documentation Report; Wageningen University: Wageningen, The Netherlands, $2007 ;$ Volume 53.

61. Li, Q.; Xue, B.; Zhao, Y.; Wu, T.; Liu, H.; Yi, X.; Sun, C.; Wang, Z.; Zou, H.; Yan, T. In Situ Degradation Kinetics of 6 Roughages and the Intestinal Digestibility of the Rumen Undegradable Protein. J. Anim. Sci. 2018, 96, 4835-4844. [CrossRef]

62. Krizsan, S.J.; Nyholm, L.; Nousiainen, J.; Südekum, K.-H.; Huhtanen, P. Comparison of in Vitro and in Situ Methods in Evaluation of Forage Digestibility in Ruminants1. J. Anim. Sci. 2012, 90, 3162-3173. [CrossRef] [PubMed]

63. Reynolds, C.K.; Crompton, L.A.; Mills, J.A.N. Improving the Efficiency of Energy Utilization in Cattle. In Proceedings of the 30th Western Nutrition Conference, Optimizing Efficiency of Animal Production, Winnipeg, Canada, 23-24 September 2009; pp. 55-65.

64. Mekuriaw, Y.; Asmare, B. Nutrient Intake, Digestibility and Growth Performance of Washera Lambs Fed Natural Pasture Hay Supplemented with Graded Levels of Ficus Thonningii(Chibha) Leaves as Replacement for Concentrate Mixture. Agr. Food Secur. 2018, 7, 30. [CrossRef]

65. Soest, P.J. Nutritional Ecology of the Ruminant, 2nd ed.; Cornell University Press: Ithaca, NY, USA, 1994; Volume 44, pp. $2552-2561$.

66. Palmonari, A.; Gallo, A.; Fustini, M.; Canestrari, G.; Masoero, F.; Sniffen, C.J.; Formigoni, A. Estimation of the Indigestible Fiber in Different Forage Types. J. Anim. Sci. 2016, 94, 248-254. [CrossRef]

67. Buckner, C.D.; Klopfenstein, T.J.; Rolfe, K.M.; Griffin, W.A.; Lamothe, M.J.; Watson, A.K.; MacDonald, J.C.; Schacht, W.H.; Schroeder, P. Ruminally Undegradable Protein Content and Digestibility for Forages Using the Mobile Bag in Situ Technique. J. Anim. Sci. 2013, 91, 2812-2822. [CrossRef] [PubMed]

68. Lopes, F.; Ruh, K.; Combs, D.K. Validation of an Approach to Predict Total-Tract Fiber Digestibility Using a Standardized in Vitro Technique for Different Diets Fed to High-Producing Dairy Cows. J. Dairy Sci. 2015, 98, 2596-2602. [CrossRef] [PubMed] 